\title{
Leadership and Decision-making Styles: Are They Relevant for Employee Retention?
}

\author{
Priscila Sardi Cerutti ${ }^{1}$ Janaina Macke ${ }^{2 *}$ João Alberto Rubim Sarate ${ }^{3}$ \\ 1.Anhanguera Educacional, R. Paissandú, 1200, Passo Fundo, Brasil \\ 2.University of Caxias do Sul (UCS), R. Francisco Getúlio Vargas, 1130, Caxias do Sul, Brasil \\ 3.Faculty CNEC Farroupilha, R. 14 de Julho, 339, Farroupilha, Brasil
}

\begin{abstract}
The aim of this study is to relate leadership and decision-making styles with the intention of remaining in the organization. The study was conducted with employees of private companies in southern Brazil. The survey research method was used, with a sample of 324 respondents. Data were submitted to factor analysis, linear regression analysis and mean difference tests. The results indicate that the transformational style together with the strategic and rational decision making had the greatest explanatory power in the intention of the employees to remain in the organization. The study contributes to leadership and decision-making research: (i) by highlighting a predominance of rational decision-making style, despite initiatives to highlight the growing importance of intuition; (ii) by assessing leadership style from the perceptions of the employees, which eliminates possible selfevaluation biases and (iii) by raising new variables to be investigated in order to remain in the job.
\end{abstract}

Keywords: leadership styles, decision-making, intention to remain in the job, survey, Brazil

DOI: $10.7176 /$ RHSS/10-2-03

Publication date: January $31^{\text {st }} 2020$

\section{Introduction}

Situations involving judgment and decision making are daily in organizations, regardless of whether the employee is in a strategic or operational position. Deciding can be a seemingly simple task in some circumstances, but it involves complex cognitive processing, as existing options must go through a judgment process, followed by decision making. Judgment and decision making are complex functions that imply the analysis of the characteristics of each option for a given decision task, as well as the estimation of the consequences of the choice to be made (Tversky \& Kahneman, 1981; Plous, 1993).

Making decisions involves choosing between actions that are usually tied to specific acts at a given time, which consequences only be visible later (Evans, Over, \& Manktelow, 1993). Decision-making style is seen as a habitual response pattern learned and exhibited by an individual when confronted with a decision situation (Scott \& Bruce, 1995). The pattern adopted when making a decision is not a characteristic of personality traits (Wood \& Highhouse, 2014), but a habit-based propensity to react in a certain way (Connor \& Becker, 2003) in a specific decision context (Evans et al., 1993; Scott \& Bruce, 1995), regardless of cognitive skills (Thunholm, 2004).

Barnard and other theorists after him, such as James March, Herbert Simon, \& Henry Mintzberg, laid the groundwork for the study of decision-making in management Nevertheless, decision making in companies depends not only on internal cognitive and psychological processes but also on contextual aspects such as leadership style (Dinh et al., 2014).

Most authors who study leadership define it as the process of influencing the activities of an individual or group to achieve a goal in each situation (Avolio, Gardner, Walumbwa, Luthans, \& May, 2004). The leadership process is a function of the leader, the led or subordinate, and situational variables. This leader-led relationship is not necessarily a hierarchical boss-subordinate relationship, but the relationship of one person trying to influenc another's behavior (Bass \& Avolio, 1993).

Among the distinct definitions of leadership found in the literature, some common elements converge, such as process, mutual influence, group context, and achievement of goals and purposes (Northouse, 2017). However, the concept of leadership is constantly changing as its perception is created according to context (Bryman, Stephens, \& Campo 2002), so more than 350 definitions are found for the term (Daft, 2005). From these definitions, different theories of leadership emerged, some of which are centered on the leader's personality, focusing on individual traits, which highlight his or her particularities, characteristics and natural qualities. Others are focused on identifying the different roles of leaders; that is, behavior begins to be considered, and different approaches to leadership styles emerge (Opoku, Ahmed, \& Cruickshank, 2015).

Research has shown that decision-making not only happens rationally (Tversky \& Kahneman, 1974), but also guided by emotion and intuition (Matzler, Uzelac, \& Bauer, 2014). Even though technological advances, such as big data, are, for one thing, allowing decisions to be more data-based (O'Connor \& Kelly, 2017; Tian, 2017), there is a growing interest in leveraging human experience through intuition in decision making (Ransbotham, Kiron, \& Prentice, 2016). After much research based on limited rationality, researchers have broadened the discussion beyond the use of reason as the main element. (Gigerenzer \& Goldstein, 1996; Isenman, 2018). 
A Web of Science search with the keywords "leadership style *" AND "intuition" yielded seven articles in management and business. These articles explored conflict management, spirituality, gender stereotypes, training, and development, and none of them linked leadership style and intuition with the intention to remain the job.

The intention to remain the job can be understood as a relatively long-lasting state of loyalty that can be described by sentences that delineate intentions, feelings, and desires to stay in the organization (Gyensare, AnkuTsede, Sanda, \& Okpoti, 2016). The desire to remain results from organizational commitment and is also related to the involvement with the objectives and management style adopted (Riaz, Akram, \& Ijaz, 2016).

Considering these arguments, the purpose of this study is to relate leadership styles and decision making with the intention to remain the job in the organization. The study was conducted with employees of private companies in the Serra Gaúcha region (southern Brazil). This article presents the main references on decision making and leadership styles. Afterward, the adopted methodological procedures and the discussion of the results are presented. Finally, final considerations highlight the main theoretical and applied contributions of the study.

\section{Decision-making styles}

According to Herbert Simon (1955), in his classic work on management decision making, decision making is a management process in itself, which comprises three stages: (i) the identification of situations that require decision making; (ii) the discovery of the various courses of action available; (iii) the choice of the most appropriate course of action.

The organization is a decision system where each person participates and formulates an opinion, according to their motivation, personality, and attitudes, i.e., decision making is influenced by the set of interventions of all people, subordinates, or managers. Decision making is the moment to choose one of several alternatives: this moment when the leader selects the course of action that seems most suitable to him or her to achieve the previously set goals (Plous, 1993; Dalal \& Bonaccio, 2010; Dinh et al., 2014).

Scott \& Bruce's (1993) theoretical model is based on five decision-making styles: rational, intuitive, dependent, evitative, and spontaneous. From their perspective, rational style questions the problem and decision in a logical and structured way, considering the various options that lead to the proposed objective. In another sense, the intuitive style intertwines in the impressions, feelings, and forebodings of its followers. Regarding the dependent style, it addresses and calls for guidance and support from others. On the other hand, people with an evitative style tend to avoid and postpone decisions, and when they make them is usually at the last moment. Regarding spontaneous style, the person with this characteristic makes impulsive decisions without prior preparation.

Individuals vary the way they make decisions, some of which engage in long deliberations, others need an immediate sense of courage, and make cognitive and systematic decisions, while others take a more affective and disorderly approach. (Hamilton, Shih, \& Mohammed, 2016). How these individuals respond to alternatives will depend, in part, on personal issues such as goals, opinions, values, and so on. The usual response to such forces indicates that the individual employs a 'decision-making' style (Connor \& Becker, 2003).

In this line of thought, the Decision-Making Styles Inventory - DMI (Nygren, 2000) was developed to measure these individual differences in decision-making styles. However, individuals are considered to have a dominant style and prevail over others, even if they use more than one style to make decisions (Driver, Brousseau, \& Hunsaker, 1990). The DMI evaluates the decisions characterized as: rational, intuitive or evitative.

The rational style is characterized by the search and logical evaluation of alternatives (Nygren \& White, 2002; Bavol'ar \& Orosova, 2015). Rational decision-making style is attributed to the use of reasoning and coherent approaches when a choice needs to be made (Scott \& Bruce, 1995). It stands out for its proactive and continuous search to identify problems and opportunities, perform extensive analysis using a formal planning process (Goll \& Rasheed, 2005)

In rational decision making, the goal is to find the best way out of the possible choices. Based on this choice, the decision-maker can obtain all possible methods and select the best one among them (Ghaleno, Pourshafei, \& Yunesi, 2015). Rational style individuals assume that goals and problems are possible to be experienced and the human mind can master all solutions logically and select the best choice (Ghaleno et al., 2015). The necessary data is collected and made available to the decision-maker and, finally, the effective factors in the decisions and results can be evaluated and shown quantitatively (Alvani, 2010).

The intuitive decision style is characterized by attention to detail and a tendency to rely on the advice of others (Bavol'ar \& Orosova, 2015). Nygren (2000) argues that intuitive-style decision-makers act with impulsiveness and carelessness, making decisions on tasks that follow the feeling of intuition. The intuitive style is defined by dependence on guesses, instinctive experience and visceral feelings (Scott \& Bruce, 1995). In this form of decision making, the individual has no clear logic regarding the true decision and, based on internal experiences and beliefs, can choose what he or she considers true (Ghaleno et al., 2015).

Under some conditions, intuitive decision making is more appropriate, such as: (i) situations where the level of uncertainty is high in the environment; (ii) situations without sufficient information; (iii) conditions in which 
there is no objective information; and (iv) situations in which there are several choices but there is no exact index to select one (Alvani, 2010).

Finally, the evitative decision style is characterized by the tendency to avoid decisions whenever possible. This style is described by a sense of immediacy and a desire to complete the decision-making process as quickly as possible (Bavol'ar \& Orosova, 2015). The evitative style is illustrated by the withdrawal, advance, retrogression and denial of decision scenarios (Scott \& Bruce, 1995). Also, evitative-style decision making is strongly related to stress (Thunholm, 2004), as individuals with this style tend to have difficulty taking the initiative in a decisionmaking situation and have a lower sense of self-esteem (Thunholm, 2008).

Evitative-style decision-makers postpone and deny decision making (Rehman, Khalid, \& Khan, 2012), delaying when they encounter problems or opportunities and delaying any reaction to problems (Ghaleno et al., 2015).

Research (Nygren \& White, 2002) using DMI showed that people who are more analytical are more likely to make rational decisions, act less impulsively, and use cognition. Thus, people who follow such a decision-making style would have a greater amount of regret than those who follow a very intuitive decision-making style (Evans, 2008). The more decisions a person makes, the more likely they are to take risks, be impulsive, have more selfesteem, and believe in luck (Evans, 2008). Most analytical decision-makers tend to spend much of their time and effort planning around decisions, while intuitive decision-makers tend to make decisions quickly without much effort (Nygren \& White, 2002).

Other researchers have found that in the organizational context, leaders with a transformational leadership style are rational decision-makers (Tambe \& Krishna, 2000) and do not shun decisions (Steplen \& Roberts, 2004). Spice \& Sadler (2005) conclude that rational decisions cannot be taken hastily and requires decision-makers' time. Thunholm's study (2008) showed that decision-makers who tend to avoid important decisions have higher levels of distress when forced to make an isolated decision. Research had shown that a decision-maker who prefers to make quick decisions showed lower levels of suffering when they were forced to decide (Thunholm, 2008).

\section{Leadership style}

Leadership is understood as a process of influence focused on activities that need to be carried out, based on actions that promote individual and collective efforts, in achieving common goals (Yukl, 2010; Northouse, 2017). Leadership in the organization can also be known as an executive position (Doh, 2002), which has the ability to encourage a group of individuals (Opoku et al., 2015), turning what was predicted into reality (Davis \& Harveston, 1999). However, leading can be much more than a process; it can be something that involves discovery and human development, while individuals are committed to achieving goals (Tabassi \& Abu-Bakar, 2010).

According to each theory, leadership is related to its main element of analysis, so for each occasion, a different style of leadership is required (Dearlove \& Coomber, 2005). For example, the trait-centered leadership (Yukl, 2010) argues that leadership ability is born with the individual; it is not acquired through experience but means the individual characteristics that define their leadership style.

On the other hand, Behavioral Theory (Bryman, 1992) believes that leaders are developed throughout experiences; They do not have an innate ability to lead, but they create behaviors according to their daily tasks. The Contingency Theory (Burns, 1978), on the other hand, argues that leadership styles should be shaped according to different leadership situations. The Transformational Leadership Theory (Bass \& Avolio, 1993), on the other hand, is concerned with relationships between individuals, advocating that leaders collaborate with those who identify needed changes, creating a vision to guide the change through inspiration for the good of the organization.

Leaders have different styles to lead, which vary and are effective according to the circumstances, attitudes, and preferences of those involved (Opoku et al., 2015). Leadership style is understood as a set of combinations coming from the leader's cognitive information, personality traits and motives and thoughts that arise according to the situations experienced (Toor \& Ofori, 2008) that the leader uses to increase his influence and that constitutes the essence of leadership (Nicolaou-Smokoviti, 2004). Moreover, the degree of authority exercised by the individual will determine their leadership style, which depends solely on their knowledge, experience, attitudes, personality behaviors, and communication (Rehman, Zahid, Rahman, \& Habib, 2019).

The leader's compliance with the beliefs, assumptions, and values that guide the organization is critical (Opoku et al., 2015) to ensure project effectiveness and organizational success (Tabassi \& Abu-Bakar, 2010). In this sense, different leadership styles have been proposed for organizational leaders, including autocratic, democratic, strategic, laissez-faire, transactional, and transformational (Table 1). Opoku et al. (2015) argue that the leadership style adopted by each leader has a major influence on organizational performance, as well as has significant impacts on organizations, whether small or large, affecting everyone from senior management to newcomers. Leadership style creates a corporate culture that will influence employee organization and performance (Iqbal, Anwar, \& Haider, 2015).

Studies have empirically investigated the relationship of leadership styles with productivity (Riaz et al., 2016; 
Asrar-ul-Haq \& Kuchinke, 2016; Mekpor \& Dartey-Baah 2017). In Pakistan, for example, the autocratic style is effective over short periods in terms of employee productivity, while, on the other hand, the democratic style is effective and statistically significant in the long run (Rehman, Rahman, Zahid, \& Asif, 2018). In Nigeria, however, the transformational style has been shown to have a significant impact on productivity, and the laissez-faire style has had a negative impact (Asrar-ul-Haq \& Kuchinke, 2016).

Another study of employees from private organizations in Ghana (Gyensare et al., 2016) investigated the impact of transformational leadership style on turnover intent using the mediating effect of affective commitment. The results showed that affective commitment completely mediates the relationship between transformational leadership style and employee turnover, served as a promoter of the degree of confidence, willingness to follow the philosophy, ideology, vision, and orientation of their leaders in the organization.

Khan \& Nawaz (2016) argue that transactional leadership style establishes a bond with employees regarding psychological and economic values. The authors noted that leadership style is critical to improving employee productivity standards and helping to reduce organizational conflicts. When compared to different leadership styles, the styles that involve employees in decision-making (such as democratic and transformational) provide for friendlier relationships and, consequently, improve organizational productivity (Riaz et al., 2016).

The study by Kedia \& Nordtvedt (2002) also concluded that there is a relationship between leadership styles and decision-making styles adopted by leaders. For example, transformational leaders use a broader style (high number of alternatives used, large amounts of information, and high coordination of different input resources) when making a decision.

\section{Method}

The research used the survey method, which allows the collection of data from a sample for subsequent quantitative treatment. The survey allows determining the incidence and distribution of the characteristics and opinions of populations of people by obtaining and studying the characteristics and opinions of small and presumably representative samples of such populations (Hair, Anderson, Tatham, \& Black, 2003). For the present study, the self-answered questionnaire was adopted.

\subsection{Questionnaire design}

The questionnaire was prepared by a team of three researchers, two seniors. Decisions about the layout questionnaire and the final approval were taken by the group of researchers during face-to-face meetings. To assess the perception of leadership styles, the Opoku et al. (2015) scale was adopted, and the decision-making perception was adopted by the Nygren (2000) scale, both measured through a Likert scale of 5 points $(1=$ strongly disagree; $5=$ strongly agree).

The questionnaire was validated through a pre-test, applied to a sample of ten respondents, representative of the different levels of position, age, company time, gender, among others. The members answered the questionnaire in a meeting of the research group to validate the collection instrument. Upon completion, they commented on the clarity of the terms, the number of questions and their understanding, the order in which they were arranged, and the Likert scale used. The instrument was validated without adjustments. The questionnaire was constructed subdivided into three parts: The first part consisted of 12 closed questions about leadership styles; the second contained 15 decision-making variables (rational, intuitive and evitative), and the third part contained the sociodemographic data (gender, age, educational background, position (chief or operational), company time, sector, company size, intention to remain in the job).

\subsection{Survey procedures}

Data collection was conducted between March and May 2019, in an online version, by the research team. Respondents were accessed from mailing lists of university students and members of the research group. Respondents were informed about the anonymity of responses and their use for academic purposes. The average response time, identified in the pretest, was around 10 minutes. The answers of the 324 respondents were organized in a spreadsheet and subsequently submitted to statistical analysis.

\subsection{Data analysis}

Data were analyzed using descriptive statistics of respondents' profile; factor analysis to the decision-making styles; Cronbach's alpha for factors reliability, linear regression analysis, and analysis of variance for sociodemographic variables (Hair et al., 2003). The researchers used the software SPSS (Statistical Package for the Social Sciences, version 20 for Windows ${ }^{\circledR}$. for data analysis.

For the decision-making scale, factor analysis and reliability test were used. Factorial analysis is a multivariate technique of interdependence in which all variables are simultaneously considered, each related to the other, to study the interrelation between them and to reduce data (Hair et al., 2003). As the leadership style scale has already been validated, there is no need for factor analysis. Linear regression analysis aims to analyze the relationship 
between variables and a dependent variable and was applied to identify the explanatory potential of leadership and decision-making styles to remain in the company.

Descriptive analyses were employed to characterize the sample of respondents, and the analysis of variance (ANOVA) was applied to verify the difference between the means of two or more groups (Hair et al., 2003).

\section{Results: analysis and discussion}

\subsection{The context: Serra Gaúcha region}

Comprising an area of $25,759 \mathrm{~km}^{2}$, the Serra Gaúcha region has a population of 1.5 million, representing about $15 \%$ of the total population of the state of Rio Grande do Sul. The region is made up of 92 municipalities, being Caxias do Sul, the largest city in the region, and an estimated population of 504,069 inhabitants. The region has specific sociocultural characteristics, such as strong German and Italian influence, large grape and wine production, and developed tourism industry (IBGE, 2018).

This region was colonized by immigrants, mainly from northern Italy, from 1875 , and the entrepreneurial activities of the colonizers made the region the first and largest center of grape and wine production in Brazil (IBRAVIN, 2019). The region's industrial activities began to gain prominence during the 1940s, along with the intensification of urbanization, when small towns became attractive cities for the workforce of smallholder farmers, who migrated to major urban centers in the region (Triches, 2002).

The Gaucho region is established as an important metal-mechanical pole of the interior of the state, portraying its diversity and dynamism, with the presence of small, medium, and large companies with high technological level. The region stands out in the industrial segments such as furniture, plastics, textiles and clothing, transport material, road implements, food, beverages, among others, which represent almost $70 \%$ of all economic activities in the region (César, 2018).

This industrial segment has more than 4,500 establishments and directly generates more than 100,000 jobs. Such characteristics make the products competitive in the national and international markets. The territorial configuration of the region has as its main axis the main highway of the country (BR-116) that unfolds on the state highway, thus creating logistical possibilities for the industrial settlement (Triches, 2002).

\subsection{Identification and analysis of leadership styles and decision-making factors}

The sample of this study comprised 324 respondents, of which $55.4 \%(\mathrm{n}=179)$ are female. Regarding time in the company, the vast majority have less than five years $(56.1 \% ; n=182)$, and $28.9 \%$ of respondents $(n=94)$ are attending higher education. Regarding the position they hold in the company, $18.1 \%(\mathrm{n}=59)$ is in a leadership position. Already, the most significant portion of respondents works in small and medium-sized companies (54\%; $\mathrm{n}=175)$, in the service area $(46.6 \% ; \mathrm{n}=151)$.

The reliability for the decision-making style scale resulted in a Cronbach's alpha of 0.691 , indicating a satisfactory level of scale reliability. The KMO test (Kaiser-Meyer-Olkin) yielded 0.766, indicating that the data is factorable (Bartlett's Test of Sphericity $(\mathrm{p}<0.01)$ ). The factor analysis used the main component of the analysis, with varimax rotation, and listwise treatment for missing values was performed in 4 iterations. The factorial analysis resulted in the three decision-making styles (Table 2). The total variance explained was $49.02 \%$, for rational style $17.45 \%$, intuitive style $15.90 \%$, and evitative style $15.67 \%$.

The rational decision making style $(\mathrm{M}=3,917 ; \mathrm{SD}=0.581)$ includes the variables: (i) "In making decisions I first try to make a mental list of all the factors or attributes that will be important to my decision"; (ii) In making decisions I first make a careful initial estimate of the situation; (iii) "In making decisions, I try to evaluate the importance of each piece of information in the decision process"; (iv) "In making decisions I try to examine the importance of the good and bad points of each alternative"; and (v) "My best decisions are those for which I've carefully weighed all of the relevant information". This style was the one that presented the highest averages, which indicates a preference of respondents for the use of rational decision making. The rational style of decision making favors the search and logical evaluation of alternatives through extensive analysis and formal planning process (Bavol'ar \& Orosova, 2015).

The intuitive decision-making style $(\mathrm{M}=3,263$; $\mathrm{SD}=0.556)$ includes the variables: (i) "I can get a good feeling for most decision situations very quickly"; (ii) "I think that relying on one's" gut feelings "is a sound decision making principle"; (iii) "When forced to make a quick decision, I find that information that readily comes to mind is usually the most useful in making a choice"; (iv) My first reaction to a decision situation usually turns out to be the best one "; and (v) "I rely on my intuition in making many of my personal decisions". This style of decision making presented the lowest averages, indicating that it has been the least adopted style by leaders/managers in the region. The use of intuition in decision making allows us to go beyond the Cartesian paradigm because by accessing other levels of consciousness, the decision-maker can gather information from a phenomenological perspective, which works with interpretations and symbolic meanings (Isenman, 2018). As average test scores demonstrated (Table 5), people in managerial positions have been making more use of intuition in decision making when compared to employees in operational roles. 
The evitative decision-making style $(\mathrm{M}=3,376 ; \mathrm{SD}=0.750)$ includes the variables: (i) "I sometimes spend too much time hesitating before making decisions"; (ii) "Before I make a decision, I think about whether others will approve or disapprove of it"; (iii) "After making a decision, I find that I often go back and re-evaluate the situation"; (iv) "When I find out that I've made a bad decision I feel a lot of regrets"; and (v) "Before I make a decision, I think about whether I might regret it later". This style of decision making was the one with the greatest dispersion of results (highest standard deviation). This result indicates that there is a greater divergence of respondents regarding the adoption of this style by leaders. This style is often used when the problem is trivial, or when there is no chance of winning because it requires a lot of time to get information, or when there is still a disagreement that can make the risk burdensome or dangerous to the organization as a whole. (Nygren, 2000; Thunholm, 2008).

Considering the leadership style results, the transformational leadership style was the most present $(\mathrm{M}=3,698$; $\mathrm{SD}=0.946$; Cronbach's alpha $=0.802$ ). The variables that made up this construct were: (i) "The leader goes beyond self-interest for the good of the organization"; (ii) "The leader considers the moral and ethical consequences of his / her decisions"; and (iii) "The leader helps others to develop their strengths." Transformational leadership aims to move followers beyond immediate interests, raising the level of maturity and ideals as well as the achievement and well-being of others, the organization, and society. In other words, leaders promote actions of collective interest (Bass \& Avolio, 1993; Schaubroeck et al., 2006; Riaz et al., 2016).

The second leadership style performance came from democratic leadership $(\mathrm{M}=3,658$; SD $=0.912$; Cronbach's alpha $=0.760$ ), indicating that there is shared responsibility and the exercise of delegation, encouraging others to become good leaders. The variables used to measure this construct were: (i) "The leader seeks to make the best decision will be the one with the largest consensus"; (ii) "The leader welcomes others to constantly challenge his / her ideas and strategies"; and (iii) "The leader tries to delegate as many tasks as possible in their complete entirety". Democratic leadership facilitates learning processes, participatory management, and organizational commitment (Heneman and Gresham, 1999; Iqbal et al., 2015).

Following, the strategic leadership style $(\mathrm{M}=3,620 ; \mathrm{SD}=0.886$; Cronbach's alpha $=0.707)$ emerged as the third most present style in the sample. The following variables were used to measure strategic leadership: (i) "The leader tends to overcome barriers to reach goals"; (ii) "The leader is good at finding practical solutions to problems"; and (iii) "The leader has a clear focus on what we need to do as an organization". Strategic leadership seeks to influence those with wisdom and a variety of behaviors to make daily decisions, increasing the company's short- and long-term viability and financial stability (Israel, 2016).

And finally, transactional leadership $(\mathrm{M}=3,308 ; \mathrm{SD}=0.885$; Cronbach's alpha $=0.649)$ achieved the lowest performance among all styles and was assessed by the variables: (i) goals are achieved "; (ii) "The leader provides recognition/rewards when others reach their goals"; and (iii) "The leader keeps track of all mistakes". Transactional leadership can help leaders and followers achieve peak performance in the organization through personal behaviors (Hayibor et al., 2011).

\subsection{The relation of leadership styles and decision-making factors with the intention to remain in the job}

The relationship between leadership style and decision making to remain in the job was tested by linear regression, using the stepwise method (Table 3). Regression results show that strategic and transformational leadership styles and rational decision-making styles accounted for $25.3 \%\left(\mathrm{R}^{2}=0.253, \mathrm{p}<0.05\right)$ of the intention to remain in the company.

In other words, the strategic and transformational leadership followed by a rational decision style are the most significant elements in employees' intention to remain in the organization (Table 4).

Table 4 shows that for each strategic leadership unit, the intention to stay with the company increases by 0.248 units; For each unit of rational style, the intention to stay in the company increases by 0.177 and for each unit of transformational leadership, the intention to stay increases by 0.237 . In other words, strategic and transformational leadership, followed by a rational decision style, are the most significant elements in employees' intention to remain in the organization.

Transformational leaders $(\mathrm{B}=0.237 ; \mathrm{p}<0.05)$ can retain their employees because they play a central role in organizational counseling and networks of influence (Bono \& Anderson, 2005), which improves employee internal motivation, morale, and commitment (Avolio et al., 2004; Piccolo and Colquitt, 2006). Motivated employees tend to stay in employment, as transformational leaders create a context conducive to team and organizational success (Resick, Whitman, Weingarden, \& Hiller, 2009). The most significant portion under talent retention responsibilities lies in the individual leader who has the transformative ability to motivate people. These leaders can provide significance to the overall work experience for the team, are much more likely to gain loyalty, especially when monetary margins are tight (Michelman, 2003).

For Avolio et al. (1999), leaders who use the transformational style of leadership are respected and admired as followers want them around to imitate them. In this leadership style, followers come first on the priority list (Bass \& Avolio 2004), and when there are transformational leaders in the organization, employee turnover rates 
are lower compared to other styles (Doran et al. 2004).

Strategic leadership style $(B=0.248 ; \mathrm{p}<0.05)$ represents the second model variable that influences talent retention. Strategic leaders are referred to as top-level executives whose decisions and actions significantly affect their organization. Their roles, roles, and decisions differ from team leaders and mid-level managers, and their effectiveness is related to the overall performance of the company. The degree to which leaders influence companies' strategies, policies, structure, and performance is critical (Mackey, 2006). Therefore, strategic leaders have a large influence on the dimensions of employee performance because, as a strategist, they are responsible for developing a vision that is robust and appropriate with employee perception (Ireland \& Hitt, 2005).

Finally, the third fact to be statistically significant in retaining organizational talent was the rational decisionmaking style $(B=0.177 ; p<0.05)$. This result is corroborated by the work of Gberevbie (2008), who argues that decision-making behavior to keep the workforce competent for organizational performance is directly linked to talent retention strategies. In this sense, previous studies (Miller, Hickson, \& Wilson, 2003; Iyayi, 2002) argue that rational organizational decisions are fundamental and necessary to facilitate the smooth functioning of organizations.

The identification of statistical differences between the means of the respondent groups was performed by analysis of variance (ANOVA). Statistically significant differences $(\mathrm{p}<0.05)$ in the variables gender, age, position in the company, economic sector, and company size were found (Table 5).

Results show that women have a higher perception of transformational leadership compared to men in this study. This result corroborates the study by Yoder (2001), which addresses the androgynous characteristics of women, as gender roles can influence leadership through the spread and internalization of specific norms, which facilitates women's focus on relevant aspects of transformational leadership, such as individualized consideration. In fact, research comparing women and men from leadership effects yielded results similar to the findings of this study, such as the study by Eagly, Johannesen-Schmidt and Van Engen (2003) which presents a meta-analysis of 45 studies comparing male and female managers on leadership style measures (transformational, transactional, and laissez-faire), with transformational leadership predominating among female respondents.

The results show statistically significant differences $(p<0.05)$ in the different age groups; Respondents between 25 and 30 years have a higher perception of transformational leadership. These findings corroborate a previous study (Barbuto, Fritz, Matkin, \& Marx, 2007) that investigated 56 leaders and 234 members to test behavioral differences attributed to gender, age and education groups. Barbuto's et al. (2007) study found a significant effect on the leader's age with a transformational leadership style, demonstrating clear differences based on the age by the leaders between 22 and 35 years old.

Considering their position in the company, employees in managerial positions have a greater perception of the intuitive style of decision making, while they have less of an evitative style of decision making. This result indicates that, because they are in leadership positions, these respondents have better skills to perceive intuition, as they probably apply an intuitive process to their decisions. Intuition in the context of decision making is a sophisticated form of reasoning and application of knowledge and experience (Kruglanski \& Gigerenzer, 2011). As for the evitative style, the research by Hariri et al. (2014) showed that executives have a lower frequency of evitative decision-making style compared to other decision-making styles. This is justified because the evitative decision-making style is characterized as relatively passive and as an attempt to avoid decision making (Scott \& Bruce, 1995).

The results also show that employees in the trade sector have a lower perception of transformational leadership, indicating a possible lack of charisma on the part of the leader (Lee \& Cho, 2018) - unlike large companies, which had high transformational leadership rates.

The industry sector has the lowest perception of democratic leadership - as the small-sized companies indicating that environmental facts are generally not concerned with delegation, consensus techniques, and participatory management (Iqbal et al., 2015). The service sector presented the highest level of strategic leadership perception, suggesting that in this segment leaders create meaning and purpose for the organization with a powerful vision and mission that creates an organizational future (Israel, 2016).

\section{Conclusions}

The present study sought to fill the research gap related to the themes of leadership styles and job tenure. To this end, it aimed to relate leadership styles and decision making with the intention to remain in the job.

The study showed that, regarding leadership, the transformational style was the one that stood out in the perception of employees. This result shows that leaders know each member of their team, their ambitions, personal values, preferences, and limitations. Leaders seem to be guided by managing trust, respect, collaboration, and commitment, pushing their followers beyond immediate interests, raising maturity, ideas, social, and organizational well-being. When analyzing decision making, the rational style was the most present, presenting the highest averages. These findings reveal a preference for respondents to use reasoning and logical approaches when making a decision, as well as the use of formal planning. 
Transformational leaders have individual consideration for each employee, implying that each employee receives the treatment they need or deserve. Hence, transformational leadership is likely to result in perceptions of fairness and equitable treatment, which are critical components and precursors of consensus among employees. Therefore, the effects of transformational leadership are directly related to the emotional commitment of employees, since the psychological attachment to the organization felt by employees is proportional to the concern and individual treatment that these leaders have with employees. Consequently, employees remain in the company because of the support they receive in the organizational environment, which provides them with opportunities for personal and professional growth and development.

The strategic leadership profile was also related to the intention to remain in the job. The strategic leader knows and takes care of every talent within work teams and is responsible for helping people understand the organizational strategy and how their work contributes to business results. These leaders aim to engage team members by communicating business goals, encouraging learning and experimentation, and providing talent expertise so that they can better serve customers and pursue the organization's strategic goals day after day. In this way, they can retain talent as they communicate to workers the business culture; make honest communications in all directions; they encourage them to include people at all stages of their work and help talents analyze the value of their contributions to the organization.

Similarly, by linking leadership styles with decision-making styles with the intention to remain in the job, the results also showed that transformational style along with strategic and rational decision-making had the greatest explanatory power in employees' intention to remain in the organization.

Evitative and intuitive decision-making styles were left out of the model. The evitative style was expected to fall outside the model because it generates insecurity and stress in the team and is not compatible with the context of technological and management changes. The intuitive style may not have entered the model because it can be difficult to evidence; Intuition-based decisions can be attributed to personality traits rather than a decision-making style.

The fact that democratic leadership has also been left out of the model may indicate that leadership that favors individual rewards and recognitions may have more impact on the decision to stay in the job than leadership more focused on collective interests. For this reason, we suggest future research to investigate specifically the styles of democratic leadership and decision-making intended for employees to remain in the job.

In sum, this study contributes to leadership and decision-making research in many ways. First, the research addresses the employee's decision-making style and the employee's perception of leadership style in the same study. Second, the findings highlight a predominance of rational decision-making style, despite initiatives to highlight the growing importance of intuition, even as responses to threats of job loss due to the advance of artificial intelligence. Third, the study assessed leadership style from the insider's perception, which eliminates possible self-evaluation biases. Finally, the study raises new variables to be investigated in retaining talent studies.

\section{Acknowledgments}

This work is being supported by the University of Caxias do Sul (Universidade de Caxias do Sul - UCS), the National Council for Scientific and Technological Development (Conselho Nacional de Desenvolvimento Científico e Tecnológico - CNPq, scholarship PQ 306199/2016-5), IMED Business School, CNEC Faculty, and the Coordination for the Improvement of Higher Education Personnel (Coordenação de Aperfeiçoamento do Pessoal de Nível Superior - Capes).

\section{References}

Alvani, S. (2010), “General management”. Tehran: Ney edition.

Antonakis, J., Avolio, B., \& Sivasubramaniam, N. (2003), Context and leadership: an examination of the ninefactor full-range leadership theory using the multifactor leadership questionnaire. The Leadership Quarterly, 14(3), 261-295.

Asrar-ul-Haq, M. \& Kuchinke, K. (2016), Impact of leadership styles on employees attitude towards their leader and performance: Empirical evidence from pakistanibanks. Future Business Journal, 2(1), 54-64.

Avolio, B., Gardner, W., Walumbwa, F., Luthans, F., \& May, D. (2004), Unlocking the mask: a look at the process by which authentic leaders impact follower attitudes and behaviors. The Leadership Quarterly, 15(6), 801823.

Barbuto, J., Fritz, S., Matkin, G., \& Marx, D. (2007), 'Effects of gender, education, and age upon leaders' use of influence tactics and full range leadership behaviors. Sex Roles, 56(34), 71-83.

Bass, B. \& Avolio, B. (1993), "Transformational leadership: a response to critique". In: M. Chemers and R. Ayman, (Eds), Leadership Theory and Research: Perspectives and Directions. Academic Press Inc., San Diego, CA.

Bavol'ar, J. \& Orosova, O. (2015), Decision-making styles and their associations with decision-making competencies and mental health. Judgment and Decision Making, 10(1), 115-127. 
Boal, K. \& Hooijberg, R. (2001), Strategic leadership research: Moring on leadership. The Leadership Quarterly, 2(4), 515-549.

Bono, J. \& Anderson, M. (2005), The advice and influence networks of transformational leaders. Journal of Applied Psychology, 90(6): 1306-1314.

Bowen, D. \& Ostroff, C. (2004), Understanding HRM-firm performance linkages: The role of the "strength" of the HRM system. Academy of Management Review, 29(2), 203-221.

Brown, G., Macleod, A., Tata, P., \& Goddard, L. (2002), Worry and the simulation of future outcomes. Anxiety, Stress and Coping, 15(1), 1-17.

Brown, M. \& Trevino, L. (2006), Ethical leadership: a review and future directions. The Leadership Quarterly, 17(6), 595-616.

Brown, R. (2005), “Rational Choice and Judgment: Decision Analysis for the Decide”. Wiley: Hoboken, NJ.

Bryman, A. (1992), "Charisma and Leadership in Organization”. Sage, London.

Bryman, A., Stephens, M., \& Campo, C. (2002), The importance of context: qualitative research and the study of leadership. The Leadership Quarterly, 7(3), 353-370.

Bubić, A. \& Erceg, N. (2016), The role of decision-making styles in explaining happiness. Journal of Happiness Studies, 19(1), 213-229.

Burns, J. (1978), “Leadership, Harper and Row”. New York, NY.

César, P. (2018), Configuração físico-territorial do setor metalomecânico da serra gaúcha e sua relação com o turismo: estudo de Caxias do Sul (RS). Revista Ateliê do Turismo, 1(2), 67-88.

Connor, B. \& Becker, W. (2003), Personal value systems and decision-making styles of public managers. Public Personnel Management, 32(1), 155-180.

Daft, R. (2005), “The Leadership Experience”. ( $3^{\text {a }}$ ed.), Thomson South-Western, Mason, OH.

Dalal, R. \& Bonaccio, S. (2010), What types of advice do decision-makers prefer?. Organizational Behavior and Human Decision Processes, 112, 11-23.

Davis, P. \& Harveston, P. (1999), In the founder's shadow: conflict in the family firm. Family Business Review, 13(4).

Dearlove, D. \& Coomber, S. (2005), “A leadership miscellany”. In Crainer, S., Goffee, R. and Yip, G. (Eds), Business Strategy Review, Autumn. Special Report: Leadership, London Business School, London.

Dinh, R., Lord, R., Gardner, W., Meuser, J., Lider, R., \& Hu, J. (2014), Leadership theory and research in the new millennium: Current theoretical trends and changing perspectives. The Leadership Quarterly, 15, 36-62.

Doh, J. (2002), Can leadership be taught? Perspectives from management educators. Academy of Management Learning and Education, 2(1), 54-67.

Doran D., McCutcheon A., Evans M., MacMillan K., Hall M., \& Pringle D. et al. (2004), "Impact of the Managers Span of Control on Leadership and Performance". Canadian Health Services Research Foundation.

Driver, M., Brousseau, K., \& Hunsaker, P. (1990), "The dynamic decision-maker: five decision styles for executive and business success". New York: Harper and Row.

Eagly, A., Johannesen-Schmidt, M., \& Van Engen, M. (2003), Transformational, transactional, and laissez-faire leadership styles: A meta-analysis comparing women and men. Psychological Bulletin, 95, 569 - 591.

Evans, J. (2008), Dual-processing accounts of reasoning, judgment, and social cognition. Annual Review Psychology, 59, 255-278.

Evans, J., Over, D., \& Manktelow, K. (1993), Reasoning, decision making and rationality. Cognition, 49, $165-$ 187.

Gberevbie, D. (2008), "Staff recruitment, retention strategies and performance of selected public and private organizations in Nigeria". PhD thesis, College of Business and Social Sciences, Covenant University, Ota.

Ghaleno, F., Pourshafei, H., \& Yunesi, M. (2015), Decision making styles of managers and its relation with their job performance in high schools of Birjand city. Science Journal, 36(3), 1-11.

Gigerenzer, G. \& Goldstein, D. (1996), Reasoning the fast and frugal way: Models of bounded rationality. Psychology Review, 103(4), 650-669.

Goll, I. \& Rasheed, A. (2005), The relationships between top management demographic characteristics, rational decision making, environmental munificence, and firm performance. Organization Studies, 26(7), 999-1023.

Gyensare, M., Anku-Tsede, O., Sanda, M., \& Okpoti, C. (2016), Transformational leadership and employee turnover intention: The mediating role of affective commitment. World Journal of Entrepreneurship, Management and Sustainable Development, 12(3), 243-266.

Hair, J., Anderson, R., Tatham, R., \& Black, W. (2003), “The Essentials of Business Research Methods". New York: John Wiley and Sons.

Hamilton, K., Shih, S., \& Mohammed, S. (2016), The development and validation of the rational and intuitive decision styles scale. Journal of Personality Assessment, 98(5), 523-535.

Hariri, H., Monypenny, R., \& Prideaux, M. (2014), Leadership styles and decision-making styles in an Indonesian school context. School Leadership and Management, 34(3), 284-298. 
Hayibor, S., Agle, B., Sears, G., Sonnenfeld, J., \& Ward, A. (2011), Value congruence and charismatic leadership in CEO-top manager relationships: an empirical investigation. Journal of Business Ethics, 102(1), 237-254.

Heneman, R. \& Gresham M. (1999), “The effects of changes in the nature of work on compensation”. Ohio state University, USA.

Hinkin, T. \& Tracey, J. (2000), The cost of turnover: Putting a price on the learning curve. The Cornell Hotel and Restaurant Administration Quarterly, 41(3), 14-21.

IBRAVIN. "Panorama setorial da uva e do vinho brasileiro". Seminário sobre Vitivinicultura. Bento Golçalves - RS. Available at: < https://www.ibravin.org.br/Dados-Estatisticos>. Acess: 11 ago. 2019.

Instituto Brasileiro de Geografia e Estatística- IBGE. (2018), Available at: $<$ https://cidades.ibge.gov.br/brasil/rs/caxias-do-sul/panorama>. Acess: 10 ago. 2019.

Iqbal, N., Anwar, S., \& Haider, N. (2015), Effect of leadership style on employee performance. Arabian Journal Business Management Review, 5(146), 1-6.

Ireland, R. \& Hitt, A. (2005), Achieving and maintaining strategic competitiveness in the 21 st century: The role of strategic leadership. Academy of Management Executive, 19(4): 63-78.

Isenman, L. (2018), “Understanding intuition: a journey in and out of science”. London: Academic Press.

Israel, A. (2016), Chief executive officer leadership role and small and medium enterprises performance in southwest Nigeria. International Journal of Advances in Management and Economics, 5(5), 40-49.

Iyayi, F. (2002), Decision-making in underdeveloped organizations: an exploratory investigation. Nigeria Journal of Business Administration, 4(1), 1-22.

Kedia, B. \& Nordtvedt, R. (2002), International business strategies, decision-making theories, and leadership styles: an integrative framework. Competitive Review, 12, 38-52.

Khan, I. \& Nawaz, A. (2016), The Leadership Styles and the Employees Performance: A Review. Gomal University Journal of Research, 32(2), 144-50.

Kruglanski, A. \& Gigerenzer, G. (2011), Intuitive and deliberate judgments are based on common principles. Psychological Review, American Psychological Association, 118(1), 34-46.

Lee, K. \& Cho, W. (2018), The relationship between transformational leadership of immediate superiors, organizational culture, and affective commitment in fitness club employees. Sport Mont, 16(1): 15-19.

Mackey A. (2008), The effect of CEOs on firm performance. Strategic Management Journal, 29(12), 1357-1367.

Mackey, A. (2008), The effect of CEOs on firm performance. Strategic Management Journal, 29, 1357-1367.

Mekpor, B. \& Dartey-Baah, K. (2017). Leadership styles and employees' voluntary work behaviors in the ghanaian banking sector. Leadership and Organization Development Journal, 38(1), 74-88.

Michelman, P. (2003), Why retention should become a core strategy now. Harvard Management Update, 5(4): 3-6.

Miller, S., Hickson, D., \& Wilson, D. (2003), “Decision-making in organizations”. In: S. Clegg, C. Hardy, and W. Nord. (Eds), Hankbook of Organization Studies, Sage: London.

Nicolaou-Smokoviti, L. (2004), Business leaders' work environment and leadership styles. Current Sociology, 52(3), 407-427.

Northouse, P. (2017), “Introduction to leadership: concepts and practice”. Thousand Oaks, CA: Sage Publications.

Nygren, T. \& White, R. (2002), "Assessing individual differences in decision making styles: Analytical vs. intuitive". Paper presented at the 46th Annual Meeting of the Human Factors and Ergonomics Society, Baltimore, MD.

Nygren, T. (2000), "Development of a measure of decision-making styles to predict performance in a dynamic J/DM task”. Paper presented at the 41st Psychonomic Society Meetings, New Orleans, LA.

Opoku, A., Ahmed, V., \& Cruickshank, H. (2015), Leadership style of sustainability professionals in the UK construction industry. Built Environment Project and Asset Management, 5(2), 184-201.

Piccolo, R. \& Colquitt, J. (2006), Transformational leadership and job behaviors: the mediating role of core job characteristics. Academy of Management Journal, 49, 327-340.

Plous, S. (1993), “The Psychology of Judgment and Decision Making”. New York: McGraw Hill.

Rehman, R., Khalid, R., \& Khan, M. (2012), Impact of employee decision making styles on organizational performance: In the moderating role of emotional intelligence. World Applied Sciences Journal, 17(10), 13081315.

Rehman, S., Rahman, H., Zahid, M., \& Asif, M. (2018), Leadership styles, organizational culture, and employees' productivity: fresh evidence from private banks of Khyber-Pakhtunkhwa, Pakistan. Journal of Social Sciences, 18, $1-15$.

Rehman, S., Zahid, M., Rahman, H., \& Habib, M. (2019), A partial least squares approach to the leadership styles, organizational culture, and employees' productivity. International Journal of Asian Business and Information Management, 10(1), 55-64.

Resick, C., Whitman, D., Weingarden, S., \& Hiller, N. (2009), The bright-side and the dark-side of CEO personality: Examining core self-evaluations, narcissism, transformational leadership, and strategic 
influence. Journal of Applied Psychology, 94(6), 1365-1381.

Riaz, T., Akram, M., \& Ijaz, H. (2016), Impact of transformational leadership style on affective employees' commitment: An empirical study of banking sector in islamabad. The Journal of Commerce, 3(1), 43-51.

Riggio, R., Zhu, W., Reina, C., \& Maroosis, J. (2010), Virtue-based measurement of ethical leadership: the leadership virtues questionnaire. Consulting Psychology Journal: Practice and Research, 62(4), 235-250.

Roets, A., Schwartz, B., \& Guan, Y. (2012), The tyranny of choice: A cross-cultural investigation of maximizingsatisficing effects on well-being. Judgment and Decision Making, 7(6), 689-704.

Schaubroeck, J., Lam, S., \& Peng, A. (2016), Can peers' ethical and transformational leadership improve coworkers' service quality? A latent growth analysis. Organizational Behavior and Human Decision Processes, 133, 45-58.

Scott, S. \& Bruce, R. (1995), Decision-making style: The development and assessment of a new measure. Educational and Psychological Measurement, 55(5), 818-831.

Scott, S. \& Bruce, R. (1994), 'Determinant of innovative behavior: A path model of individual innovation in the workplace'. Academy of Management Journal, 37, 580-607.

Simon H. (1955), A behavioral model of rational choice. Quarterly Journal of Economics, 69, 99-118.

Spice, D. \& Sadler, E. (2005), An examination of general decision-making style questionnaire in two UK samples. Journal of Managerial Psychology, 20(2), 137-149.

Steplen, H. \& Roberts, T. (2004), “Transformational leadership creating organization of meaning”. New York: ASQ Quality Press.

Tabassi, A. \& Abu-Bakar, A. (2010), Towards assessing the leadership style and quality of transformational leadership: the case of construction firms of Iran. Journal of Technology Management in China, 5(3), 245258.

Tambe, A. \& Krishna, V. (2000), Leadership in decision making. Indian Management, 39(1), 69-79.

Thunholm, P. (2008), Decision-making styles and physiological correlates of negative stress: Is there a relation? Scandinavian Journal of Psychology, 49, 213-219.

Thunholm, P. (2004), Decision-making style: Habit, style or both? Personality and Individual Differences, 36(4), 931-944.

Toor, S. \& Ofori, G. (2008), Leadership for future construction industry: agenda for authentic leadership. International Journal of Project Management, 26(6), 620-630.

Triches, D. (2002). Agropólo da Serra Gaúcha: uma alternativa de desenvolvimento regional a partir da inovação e difusão tecnológica. Revista Baiana de Tecnologia, 17(2), 47-56.

Tversky, A. \& Kahneman, D. (1981), The framing of decisions and the psychology of choice. Science, 211, $453-$ 458.

Wood, N. \& Highhouse, S. (2014), Do self-reported decision styles relate with others' impressions of decision quality? Personality and Individual Differences, 70, 224-228.

Yoder, J. (2001), Making leadership work more effectively for women. Journal of Social Issues, 57, 815 - 828.

Yukl, G. (2010), “Leadership in organizations". (7 $7^{\mathrm{a}}$ ed.). New York: Pearson Education.

Zaccaro, S. (1995), Leader resources and the nature of organizational problems: Commentary on Cognitive resources and leadership by Fred E. Fiedler. Applied Psychology, 44(5): 32-36.

Zaccaro, S. (1996), "Models and Theories of Leadership". U.S. Army Research Institute for the Behavioral and Social Sciences, Alexandria, VA.

Zhu, W., Riggio, R., Avolio, B., \& Sosik, J. (2011), The effect of leadership on follower moral identity: does transformational/transactional style make a difference? Journal of Leadership and Organizational Studies, 18(2), 150-163.

Priscila Sardi Cerutti - Casca (Brazil), March 20 ${ }^{\text {th }}$, 1991. Master degree in Business Administration (2019) at IMED Business School, Passo Fundo, Brazil. Bachelor degree in Psychology (2012) at IMED Psychology School, Passo Fundo, Brazil. Her main topics of interest are leadership, organizational psychology and health and quality of life at work.

Janaina Macke - Taquara (Brazil), July $3^{\text {rd }}$, 1975. Post-doctoral degree in Territorial Science (2013) at University Joseph Fourier, Grenoble, France. Doctoral degree in Business Administration (2005) at Federal University of Rio Grande do Sul (UFRGS), Porto Alegre, Brazil. Master degree in Production Engineering (1999) at Federal University of Rio Grande do Sul (UFRGS), Porto Alegre, Brazil. Bachelor degree in Civil Engineering (1997) at Federal University of Rio Grande do Sul (UFRGS), Porto Alegre, Brazil. Her main topics of interest are competencies, social capital, collective action, territorial development.

João Alberto Rubim Sarate - Porto Alegre (Brazil), September 13 ${ }^{\text {th }}$, 1969. Post-doctoral degree in Resilient Territories (2019) at University of Agder, Kristiansand, Norway. Doctoral degree in Business Administration 
(2014) at Federal University of Rio Grande do Sul (UFRGS), Porto Alegre, Brazil with double degree with University Pierre Mendes, Grenoble, France. Master degree in Business Administration (2008) at Unisinos University (Unisinos), Porto Alegre, Brazil. Bachelor degree in Mechanical Engineering (1996) at Federal University of Rio Grande do Sul (UFRGS), Porto Alegre, Brazil. His main topics of interest are territorial development, social innovation and leadership for sustainability.

Table 1. Leadership style: democratic, strategic, transactional and transformational

\begin{tabular}{|c|c|c|}
\hline $\begin{array}{c}\text { Leadership } \\
\text { style }\end{array}$ & Main features & Authors \\
\hline Democratic & $\begin{array}{l}\text { - Democratic leaders follow a style of sharing philosophy; } \\
\text { - Decisions are made within the team, with equal participation } \\
\text { among all members of the organization; } \\
\text { - This style generates more employee commitment to meeting the } \\
\text { goals of each department as well as meeting deadlines; } \\
\text { - There is a sharing of responsibilities and the exercise of } \\
\text { delegation, encouraging others to become good leaders. }\end{array}$ & $\begin{array}{l}\text { Heneman and } \\
\text { Gresham (1999) } \\
\text { Iqbal et al. (2015) }\end{array}$ \\
\hline Strategic & $\begin{array}{l}\text { - The essence of strategic leadership involves not only the ability to } \\
\text { learn and change but also to exercise managerial wisdom; } \\
\text { - Strategic leaders influence others wisely and with a variety of } \\
\text { behaviors to make daily decisions, increasing the company's short- } \\
\text { and long-term viability and financial stability; } \\
\text { - Strategic leaders seem to move forward in time to set directions } \\
\text { for the organization. They create meaning and purpose for the } \\
\text { organization with a powerful vision and mission that creates an } \\
\text { organizational future; } \\
\text { - Strategic-style leaders are called top-level executives whose } \\
\text { decisions and actions significantly affect their organization. Their } \\
\text { roles, roles, and decisions are different from team leaders and } \\
\text { middle managers, and their effectiveness is related to the overall } \\
\text { performance of the company. }\end{array}$ & $\begin{array}{l}\text { Zaccaro (1996) } \\
\text { Boal and Hooijberg } \\
(2001) \\
\text { Mackey (2008) } \\
\text { Israel } \\
(2016)\end{array}$ \\
\hline Transactional & $\begin{array}{l}\text { - The moral standards set in the organization are enforced through } \\
\text { effective, ethical frameworks, as transactional leaders positively } \\
\text { impact the morale of their followers; } \\
\text { - The personal values of each leader are shaped by other leaders, as } \\
\text { they are considered visionaries and promoters of good } \\
\text { relationships; } \\
\text { - Decisions made in the organization are fair and balanced, using } \\
\text { rewards and punishments in the workplace; } \\
\text { - The leader seeks to achieve maximum performance in the } \\
\text { organization through personal behaviors; } \\
\text { - The leader rewards followers for achieving performance goals. } \\
\text { This type of leader focuses on the role of supervision, organization, } \\
\text { and performance of the group; } \\
\text { - Ethical leaders have honesty, fairness, fortitude, and prudence as } \\
\text { personal characteristics and actions. }\end{array}$ & $\begin{array}{l}\text { Zhu, Riggio, Avolio } \\
\text { and Sosik } \\
\text { (2011) } \\
\text { Brown and Trevino } \\
(2006) \\
\text { Riggio, Zhu, Reina a } \\
\text { Maroosis, (2010) } \\
\text { Hayibor, Agle, } \\
\text { Sears, Sonnenfeld } \\
\text { and Ward (2011) }\end{array}$ \\
\hline Transformational & $\begin{array}{l}\text { - The leader seeks to motivate employees to perform better than } \\
\text { expected by the organization, thinking not only of individual } \\
\text { interests but working together for shared causes; } \\
\text { - Employees are led by the leader's example, which influences } \\
\text { morally, emotionally, emotionally, and cognitively, with positive } \\
\text { and ethical qualities; } \\
\text { - decisions made by leaders are for the promotion of ethical and } \\
\text { innovative policies, procedures and processes in organizations; } \\
\text { - The leader exhibits charisma, developing a vision, respect, and } \\
\text { trust. It pays attention to followers and provides intellectual } \\
\text { stimulation, challenging them with new ideas and approaches; } \\
\text { - Leaders move followers beyond immediate interests, raising the } \\
\text { level of maturity and ideals concerning the achievement and well- } \\
\text { being of others, the organization, and society. }\end{array}$ & $\begin{array}{l}\text { Schaubroeck, Lam } \\
\text { and Peng (2006) } \\
\text { Zhu et al. (2011) } \\
\text { Opoku et al. (2015) } \\
\text { Israel (2016) } \\
\text { Rehman et al. (2019) }\end{array}$ \\
\hline
\end{tabular}


Table 2. Factorial results for decision making

\begin{tabular}{|c|c|c|c|c|}
\hline Factor & Items & Loading & Mean & $\begin{array}{l}\text { Standard } \\
\text { deviation }\end{array}$ \\
\hline \multirow{5}{*}{$\begin{array}{l}\text { Rational } \\
\text { style } \\
(0.740)^{*}\end{array}$} & $\begin{array}{l}19 \text { - In making decisions, I first try to make a mental list of } \\
\text { all the factors or attributes that will be important to my } \\
\text { decision. }\end{array}$ & 0.706 & 3.85 & 0.837 \\
\hline & $\begin{array}{l}20 \text { - In making decisions I first make a careful initial estimate } \\
\text { of the situation }\end{array}$ & 0.763 & 3.78 & 0.833 \\
\hline & $\begin{array}{l}21 \text { - In making decisions I try to evaluate the importance of } \\
\text { each piece of information in the decision process }\end{array}$ & 0.758 & 3.99 & 0.795 \\
\hline & $\begin{array}{l}22 \text { - In making decisions I try to examine the importance of } \\
\text { the good and bad points of each alternative }\end{array}$ & 0.735 & 4.01 & 0.785 \\
\hline & $\begin{array}{l}23 \text { - My best decisions are those for which I've carefully } \\
\text { weighed all of the relevant information }\end{array}$ & 0.537 & 3.96 & 0.866 \\
\hline \multirow{5}{*}{$\begin{array}{l}\text { Intuitive } \\
\text { style } \\
(0.720)^{*}\end{array}$} & $\begin{array}{l}24 \text { - I can get a good "feeling" for most decision situations } \\
\text { very quickly }\end{array}$ & 0.609 & 3.50 & 0.922 \\
\hline & $\begin{array}{l}25 \text { - I think that relying on one's "gut feelings" is a sound } \\
\text { decision making principle }\end{array}$ & 0.690 & 3.14 & 1.061 \\
\hline & $\begin{array}{l}26 \text { - When forced to make a quick decision, I find that } \\
\text { information that readily comes to mind is usually the most } \\
\text { useful in making a choice }\end{array}$ & 0.711 & 3.19 & 0.902 \\
\hline & $\begin{array}{l}27 \text { - My first reaction to a decision situation usually turns out } \\
\text { to be the best one }\end{array}$ & 0.687 & 3.10 & 0.928 \\
\hline & $\begin{array}{l}28 \text { - I rely on my intuition in making many of my personal } \\
\text { decisions }\end{array}$ & 0.726 & 3.38 & 0.958 \\
\hline \multirow{5}{*}{$\begin{array}{l}\text { Evitative } \\
\text { style } \\
(0.706)^{*}\end{array}$} & $\begin{array}{l}29 \text { - I sometimes spend too much time hesitating before } \\
\text { making decisions }\end{array}$ & 0.624 & 3.23 & 1.021 \\
\hline & $\begin{array}{l}30 \text { - Before I make a decision, I think about whether others } \\
\text { will approve or disapprove of it }\end{array}$ & 0.760 & 3.31 & 1.142 \\
\hline & $\begin{array}{l}31 \text { - After making a decision, I find that I often go back and } \\
\text { re-evaluate the situation }\end{array}$ & 0.655 & 3.29 & 0.987 \\
\hline & $\begin{array}{l}32 \text { - When I find out that I've made a bad decision I feel a } \\
\text { lot of regrets }\end{array}$ & 0.659 & 3.66 & 1.189 \\
\hline & $\begin{array}{l}33 \text { - Before I make a decision, I think about whether I might } \\
\text { regret it later }\end{array}$ & 0.658 & 3.39 & 1.176 \\
\hline
\end{tabular}

Note:

*Cronbach's Alpha

Table 3. Linear regression model

\begin{tabular}{r|c|r|r|r|c}
\hline Model & R & R Square & $\begin{array}{c}\text { Adjusted R } \\
\text { Square }\end{array}$ & $\begin{array}{c}\text { St. Error of the } \\
\text { Estimate }\end{array}$ & Durbin-Watson \\
\hline 1 & $0.456^{\mathrm{a}}$ & 0.208 & 0.206 & 0.8916 & \\
\hline 2 & $0.487^{\mathrm{b}}$ & 0.238 & 0.233 & 0.8763 & \\
\hline 3 & $0.510^{\mathrm{c}}$ & 0.260 & $\mathbf{0 . 2 5 3}$ & 0.8646 & 1.792 \\
\hline
\end{tabular}

Note:
a. Predictors: (Constant), Strategic leadership
b. Predictors: (Constant), Strategic leadership, Rational style
c. Predictors: (Constant), Strategic leadership, Rational style, Transformational leadership
d. Dependent Variable: I intend to remain on this job. 
Table 4. Linear regression coefficients

\begin{tabular}{|c|c|c|c|c|c|}
\hline \multirow[b]{2}{*}{ Final Model } & \multicolumn{2}{|c|}{ Unstandardized } & \multirow{2}{*}{$\begin{array}{c}\text { Standardized } \\
\text { Beta }\end{array}$} & \multirow[b]{2}{*}{$\mathbf{t}$} & \multirow[b]{2}{*}{ Sig. } \\
\hline & B & $\begin{array}{c}\text { Std. } \\
\text { Error }\end{array}$ & & & \\
\hline (Constant) & -3.133 & 0.367 & & -8.526 & 0.000 \\
\hline Strategic leadership & 0.279 & 0.086 & 0.248 & 3.238 & 0.001 \\
\hline Rational style & 0.305 & 0.084 & 0.177 & 3.642 & 0.000 \\
\hline Transformational leadership & 0.250 & 0.080 & 0.237 & 3.116 & 0.002 \\
\hline
\end{tabular}

\section{Note:}

a. Dependent Variable: I intend to remain on this job

\begin{tabular}{lccl}
\multicolumn{1}{c}{ Table 5. ANOVA } \\
\hline Variable & F & Sig. & Result \\
Sex & 3.980 & 0.047 & $\begin{array}{l}\text { - Women have a higher perception of Transformational } \\
\text { leadership. }\end{array}$ \\
Age & 2.531 & 0.041 & $\begin{array}{l}\text { - People between 25 and 30 years old have higher } \\
\text { Transformational leadership perception. }\end{array}$
\end{tabular}

$\begin{array}{llll}\text { Chief } & 6.363 & 0.012 & \text { - People in the chief position have a more Intuition style. } \\ \text { position } & 11.498 & 0.001 & \text { - People in the chief position have less Evitative style. }\end{array}$

\begin{tabular}{llll}
\hline 7.288 & 0.001 & $\begin{array}{l}\text { - Trade sector has a lower perception of Transformational } \\
\text { leadership. }\end{array}$ \\
& 5.474 & 0.005 & $\begin{array}{l}\text { - Industry sector has a lower perception of Democratic } \\
\text { leadership. }\end{array}$ \\
$\begin{array}{l}\text { Economy } \\
\text { sector }\end{array}$ & 3.264 & 0.040 & - Service sector has a higher perception of Strategic leadership. \\
& 4.677 & 0.010 & - Trade sector has a higher perception of Intuitive style. \\
& 0.019 & $\begin{array}{l}\text { - Industry sector has a lower perception of Evitative style. } \\
\text { Company size }\end{array}$ \\
4.279 & 0.015 & $\begin{array}{l}\text { - Large-size companies have higher Transformational leadership } \\
\text { perception. }\end{array}$ \\
\hline
\end{tabular}

